\title{
Ginkgo biloba modulates hippocampal BDNF expression in a rat model of chronic restraint stress-induced depression
}

\author{
Seyed Abdolmajid Ayatollahi ${ }^{1,2 \#}$, Shahrokh Khoshsirat ${ }^{3 \#}$, Ali Asghar Peyvandi ${ }^{3}$, Omidvar Rezaei $^{4}$, \\ Fatemeh Zare Mehrjardi ${ }^{5}$, Arezo Nahavandi ${ }^{6}$, Somayeh Niknazar ${ }^{3,4^{*}}$ iD \\ 1. Phytochemistry Research Center, Shahid Beheshti University of Medical Sciences, Tehran, Iran \\ 2. Department of Pharmacognosy, School of Pharmacy, Shahid Beheshti University of Medical Sciences, Tehran, Iran \\ 3. Hearing Disorders Research Center, Loghman Hakim Medical Center, Shahid Beheshti University of Medical Sciences, Tehran, Iran \\ 4. Skull Base Research Center, Loghman Hakim Medical Center, Shahid Beheshti University of Medical Sciences, Tehran, Iran \\ 5. Neurobiomedical Research Center, School of Medicine, Shahid Sadoughi University of Medical Sciences and Health Services, \\ Yazd, Iran \\ 6. Neuroscience Research Center, Department of Physiology, Iran University of Medical Sciences, Tehran, Iran
}

\begin{abstract}
Introduction: Mood disorders such as depression and anxiety disorders have been affecting a relatively high proportion of the world's population. Neuroplasticity hypothesis of depression proposes that lack of brain-derived neurotrophic factor (BDNF) can cause structural changes in the brain. The extract of Ginkgo biloba (Gb) leaves can restore much of the damage in the nervous system. We examined the antidepressant role of $\mathrm{Gb}$ extract (EGb 761) on BDNF expression modulation in the hippocampus of rats subjected to repeated restraint stress (RRS).
\end{abstract}

Methods: Adult male rats were randomly divided into 10 groups: control, controlvehicle treated, stress, stress-vehicle treated, as well as three control and three experimental groups pretreated with EGb $(15,30,60 \mathrm{mg} / \mathrm{kg}$, IP daily) for 21 days. They underwent restraint stress on a daily basis, 6 hours for 21 consecutive days. Weight changes, locomotor activity and forced swim test (FST) were employed to assess depressive-like symptoms. The serum corticosterone level was also measured by ELISA. Hippocampal BDNF DNA methylation and protein expression were assayed by methylation sensitive restriction enzymes (Real Time PCR) and Westernblotting respectively in all groups.

Results: Pre-treatment with 30 and $60 \mathrm{mg} / \mathrm{kg} / \mathrm{day}$ of $\mathrm{Gb}$ extract significantly attenuated depressive-like effects in the body weight, FST and serum corticosterone level in RSS rats compared to control groups. Further, it inhibited chronic stressinduced alterations in the hippocampal BDNF DNA methylation and protein expression.

Conclusion: These findings suggest that $\mathrm{Gb}$ can induce an antidepressant role through its modulation effect on the hippocampal BDNF expression.

\section{Keywords:}

Repeated Restraint Stress; Ginkgo biloba; Depression; DNA Methylation; BDNF expression

\section{* Corresponding author:}

S. Niknazar

Email:

niknazar@sbmu.ac.ir Tel: (+98) 02151025182

\#These authors contributed equally to this study

Received 4 November 2019; Received in revised form 26 May 2020; Accepted 8 June 2020 


\section{Introduction}

Mood disorders such as depression and anxiety disorders affect a relatively high percentage of the world population (Bakhtiarzadeh et al., 2018; Belmaker and Agam, 2003; Noori-Daloii et al., 2015; Mineka et al., 1998). Major depression disorder (MDD) is the third most common mental illness of the modern world. Evidence suggests that the prevalence of MDD is growing across the population (Hidaka, 2012). Depression is one of the most common mental disorders worldwide. Several hypotheses have been proposed for the mechanisms and pathophysiology of depression. However, despite extensive research, the pathophysiology and treatment of this disease are not fully understood. Post-mortem studies of brain structure in depressed patients have identified abnormalities such as hippocampal volume reduction, apoptosis and molecular changes (Malykhin and Coupland, 2015).

Brain-derived neurotrophic factor (BDNF) has been identified as a stress-responsive gene. The role of BDNF in stress-related disorders has been studied for several years. Evidence suggests that BDNF protects neurons under chemical stress conditions (Spina et al., 1992). In 1995, Smith et al. reported that BDNF expression in the brain was regulated by stress. Others have also determined the role of BDNF in recurrent depression, aging and post-traumatic stress disorder (Smith et al., 1995a; Smith et al., 1995b). The neuroplasticity hypothesis of depression suggests that altered synthesis and/or release of neurotrophins such as BDNF can contribute to the depression pathogenesis (Hashimoto et al., 2004). Environmental factors can also contribute to epigenetic changes in DNA that could influence gene activity, protein expression and organism function (Jaenisch and Bird, 2003). Epigenetic modifications are usually associated with DNA methylation or histone modifications that can contribute to increase or suppress gene transcription (Vaissière et al., 2008). Recent studies have indicated the epigenetic changes of the BDNF gene in response to external stimuli such as social stress and electroconvulsive seizures (Tsankova et al., 2006; Tsankova et al., 2004). Roth et al. (2011) indicated that chronic exposure to psychosocial stress induces hypermethylation of the promoter IV region of BDNF and in turn diminished BDNF expression in the rat hippocampus. In addition, increased DNA methylation exon IV in the hippocampus of mice was also associated with depression-related behaviour (Onishchenko et al., 2008). Today, medicinal herbs as one of the conventional approaches are applied to prevent and treat depression and anxiety disorders. The Ginkgo biloba $(\mathrm{Gb})$ leaves and seeds were used in Chinese herbal medicine for centuries (Howes and Houghton, 2003; Sarris et al., 2011). The extract of $\mathrm{Gb}$ leaves can restore much of the damage to the nervous system (Chandrasekaran et al., 2001; Woelk et al., 2007). Although its role in improving depression in animals has been proposed, with respect to the complexity of chemical composition and multiple mechanisms of $\mathrm{Gb}$, studies continue to determine the physiological basis of the $\mathrm{Gb}$ effect on depression. Based on the above-mentioned data, we examined the antidepressant effect of $\mathrm{Gb}$ through modulation of BDNF DNA methylation and protein expression in the hippocampus of rats.

\section{Materials and methods}

\section{Animals}

For this study, adult male Wistar rats $(n=60,230$ 250g, 3 months) were obtained from Shahid Beheshti Medical University, Animal Experiment Centre. They were allowed to adapt to the laboratory environment 1 week before the experiment was started. They were held in Type T IV cages $(n=6)$ at constant temperatures $\left(21 \pm 1^{\circ} \mathrm{C}\right)$ and $12: 12 \mathrm{~h}$ light / dark cycle with free access to standard diet and water. Male rats were randomly assigned into 10 equal groups $(n=6)$ : control, control group treated with vehicle (saline, IP), stress, stressed group treated with vehicle (saline, IP), as well as three control and three experimental groups treated with EGb 15, 30, $60 \mathrm{mg} / \mathrm{kg}$ (dissolved in sterile saline, administered IP $30 \mathrm{~min}$ before each stress episode). This study was confirmed by the Ethics Committee of Shahid Beheshti University of Medical Sciences (IR.SBMU.REC.1396.95) based on National Institutes of Health Publication guide for the care and use of laboratory. Experimental samples of ginkgo plant were prepared in accordance with the US Pharmacopoeia method (United State Pharmacopeias) USP 28, NF23. The $1.0 \mathrm{~g}$ of ginkgo biloba powdered was passed to a $250 \mathrm{ml}$ Erlenmeyer flask and add $50 \mathrm{ml}$ ethanol, $20 \mathrm{ml}$ water and $8 \mathrm{ml}$ hydrochloric acid. The mixture solution was refluxed for $135 \mathrm{~min}$. Once the sample was cooled to room temperature, it was filtered into $100 \mathrm{ml}$ volumetric 
flask, then diluted with water to volume and well mixed by inversion. A sample aliquot was filtered and prepared for analysis with HPLC. Standardized Gb extract (EGb 761) utilized in the present research contained $24 \%$ flavanol glycosides, $6 \%$ terpene lactones and trace amounts of other substances such as proanthocyanidins and organic acids (DeFeudis, 2003; Yoshitake et al., 2010).

\section{Stress procedure}

Stress session involved 6 hours (8am to $2 \mathrm{pm}$ ) of immobilization period inside a cylindrical tube (with holes for ventilation) at room temperature. Each restraint session was conducted for 21 consecutive days. Control animals were habituated by daily handling and sacrificed through decapitation at the same time.

\section{Body weight}

The weight data of all rats were collected on day 0 (before) and day 21 (last day) of the repeated restraint stress (RRS).

\section{Locomotion assay}

A square-shaped box (Infrared Locomotor Cage, $40 \times 40 \times 40 \mathrm{~cm}$ ) made of transparent Plexiglas with a wire mesh floor was used for the locomotor activity. When a rat was placed in the centre of the chamber, the movement of animal was recorded through breaking invisible infrared by an analyser in $5 \mathrm{~min}$.

\section{Forced swim test (FST)}

FST was performed in accordance with the method of Porsolt et al. (1979). It was performed in two sessions with animals placed in a cylindrical tank. In the first session (pre-test), they were trained for 15min in water. One day after the experiment, the rats were tested through FST for $5 \mathrm{~min}$. In summary, the rats were forced to swim in a glass. Initially, the rats swam around vigorously. A few minutes later, their activity decreased and finally they started to turn immobile and just floated in the water in an upright position. FST was employed after completion of 21 days of the stress phase. Immobility time was measured during the $5 \mathrm{~min}$ period.

\section{Serum corticosterone assay}

Forty-eight hours after the final restraint stress, blood samples were collected via cardiac puncture between
9:30 and 10:30am. The samples were collected from rats under deep terminal anaesthesia immediately prior to decapitation to guarantee correct measurements of corticosterone level while remaining unaffected by blood withdrawal. Intracardiac puncture - a terminal blood collection method - is a suitable technique to obtain a single, large and good quality sample from a euthanized rat. At the end of the experiment, the animals were sacrificed (Parasuraman et al., 2010). The serum was isolated from the blood through centrifugation at $3000 \mathrm{rpm}, 4^{\circ} \mathrm{C}$ for $15 \mathrm{~min}$. The ELISA kit (AlpcoDiagnostics, USA) was used to check the serum corticosterone levels.

\section{Hippocampal samples' preparation}

Under deep anaesthesia, animals were sacrificed. Briefly, after removing the skull, the brain was extracted and placed in an ice-cold phosphatebuffered saline solution. The brain was cut along the longitudinal fissure or interhemispheric fissure of the cerebrum using a surgical knife. The mid brain was discarded and the hippocampus was isolated from each brain hemisphere. The entire hippocampus tissues were dissected and frozen in liquid nitrogen and then stored at $-80^{\circ} \mathrm{C}$ until conducting molecular assay.

\section{Methylation procedure and Real Time PCR}

Hippocampal genomic DNA was prepared using KoGeneBioTech kit. Hpall and Mspl (New England Biolabs, MA) restriction enzymes were used for digestion of DNA samples. Both enzymes recognize the same site (CCGG). Methylated cytosine residue in DNA can be detected by Hpall but not Mspl. Genomic DNA $(1 \mu \mathrm{g})$ was diluted by NEBuffer1 $(50 \mu \mathrm{l})$ (New England Biolabs, MA) and then subdivided into three aliquots. Two separate aliquots of DNA were digested with the Hpall or Mspl, while the third aliquot was undigested and considered as the background control. The reaction mix was incubated for $2 \mathrm{~h}$ at $37^{\circ} \mathrm{C}$ and then stored at $-20^{\circ} \mathrm{C}$. PCR amplifications were carried out in $20 \mu \mathrm{l}$ reaction mixtures by Step One $^{T M}$ Plus system (PE, Applied Biosystems, CA). Also, methylated DNA associated with BDNF exons was detected using the following primers: forward (5'_AAG ACT GCA GTG GAC ATG TCC_3') and reverse (5'_CCT TCG TGT AAC CCA TGG GAT_3'). 
Table 1: Effect of EGb treatment on body weight and weight gain of stressed rats (mean \pm SEM).

\begin{tabular}{|c|c|c|c|}
\hline \multirow[t]{2}{*}{ Group } & \multicolumn{2}{|c|}{$B W(g)$} & \multirow{2}{*}{ WG } \\
\hline & Day 0 & Day 21 & \\
\hline Control & $241.3 \pm 0.6$ & $317.5 \pm 0.7^{\alpha}$ & $76.1 \pm .6$ \\
\hline Control- Vehicle & $242.5 \pm 0.7$ & $318.0 \pm 1^{\alpha}$ & $75.6 \pm 1.2$ \\
\hline Stress & $244.5 \pm 1.3$ & $280.7 \pm 1.5^{\alpha}$ & $36 \pm 2 .^{\alpha}$ \\
\hline Stress - Vehicle & 244. \pm 1.29 & $281.7 \pm 1.4^{\alpha}$ & $37.6 \pm 2.2^{\alpha}$ \\
\hline Control- EGB 15 mg/kg & $241.7 \pm 2$ & $313 \pm 1.39^{\alpha}$ & $71.3 \pm 3.2$ \\
\hline Control- EGB 30 mg/kg & $242.7 \pm 1.8$ & $312 \pm 2.9^{\alpha}$ & $70.1 \pm 2.2$ \\
\hline Control- EGB 60 mg/kg & $244 \pm 1.59$ & $311 \pm 3.83^{a}$ & $67 \pm 3.8$ \\
\hline Stress- EGB 15 mg/kg & $239.5 \pm 1.2$ & $279.7 \pm 2.3^{\alpha}$ & $40.1 \pm 1.8^{\alpha}$ \\
\hline Stress- EGB & $241.5 \pm 2.7$ & $306 \pm 4.9^{\alpha}$ & $64.6 \pm 6.3^{\$ \Phi}$ \\
\hline Stress- EGB & $243.5 \pm 1.4$ & $313 \pm 1.1^{\alpha}$ & $69.5 \pm 1.6^{\Phi}$ \\
\hline
\end{tabular}

Body weight of male rats on day 21 (last day) compared to day 0 (before) of chronic stress phase (Student's $t$ test). Effect of $\mathrm{Gb}$ treatment on of stressed rats. EGb: Ginkgo biloba extract, BW: body weight, WG: weight gain. ${ }^{\alpha} P<0.001$ compared to day 0 , control, control - vehicle and control-EGB treated $\left(15,30\right.$ and $60 \mathrm{mg} / \mathrm{kg}$ ) groups; ${ }^{\$} P<0.05$ compared to control and control -vehicle groups; ${ }^{\Phi} P<0.001$ compared to stress, stress- vehicle and stress- EGB treated $(15 \mathrm{mg} / \mathrm{kg})$ groups. Data were analyzed by One-way ANOVA.

PCR thermo-cycling steps were as follows: 40 cycles of $94^{\circ} \mathrm{C}$ for $15 \mathrm{~s}$, then $63^{\circ} \mathrm{C}$ for $30 \mathrm{~s}$ and $72^{\circ} \mathrm{C}$ for $30 \mathrm{~s}$ followed by $72^{\circ} \mathrm{C}$ for $10 \mathrm{~min}$. All SYBR Green (PR081A, TaKaRa) PCR assays were performed in 96-well optical plates in duplicate for every DNA sample. The $\triangle \triangle C T$ for each sample was determined by the following equation: $\triangle \triangle C T=\Delta C T$ (MSPI-UD) $\Delta C T$ (Hpall-UD) (Niknazar et al., 2016).

\section{Western blot assay}

Western blot assay was performed on the hippocampus of rats as previously described (Niknazar et al., 2017b). In summary, the frozen hippocampus was homogenized with ice-cold lysis buffer system (Santa Cruz Biotechnology, sc-24948, USA). Total proteins were separated on SDS - PAGE and transferred onto nitrocellulose membranes. After the blocking step, the membrane was probed with primary antibodies for BDNF (AB, 6201, 1-1000; Abcam, Cambridge, UK) and $\beta$ Actin (AB, ab8227,12000; Abcam , Cambridge, UK) (as an internal control). Then washed with TBST three times for $10 \mathrm{~min}$, and eventually incubated with HRPconjugated anti-rabbit IgG secondary antibody ( $A B$, 6721,1-2000; Abcam, Cambridge, UK) for $2 \mathrm{~h}$ at room temperature. The blots were visualized using an ECLadvanced chemiluminescence detection kit
(Amersham Pharmacia Biotech Inc, Piscataway, NJ, USA) after which the film was exposed to $x$-rays. The scanned film signals were analysed by TotalLab software (Nonlinear Dynamics Ltd, USA).

\section{Data analysis}

Data have been represented as mean \pm SEM. Statistical significance was analysed by Graph Pad Prism version 5.04 Windows (Graph Pad Software, San Diego, CA, USA). Statistical significance was detected by the Student's t test and One-way ANOVA followed by post-hoc Tukey's test to compare the differences between groups. $P<0.05$ was considered significant.

\section{Results}

\section{Effects of $\mathrm{Gb}$ extract on body weight changes in} the stressed rat

Following the course of 21 days of stress phase, the body weight was significantly elevated in control $(n=6)$, stressed $(n=6)$ and experimental $(n=6)$ groups compared to day $0(P<0.001$, Table 1$)$. However, the weight gain was significantly reduced in stressed $(P<0.001)$ and experimental groups treated with $\mathrm{EGb}$ $15(P<0.001)$ and $30 \mathrm{mg} / \mathrm{kg}(P<0.05)$ compared to the non-stressed groups. On the other hand, weight gain was significantly intensified in groups administered 

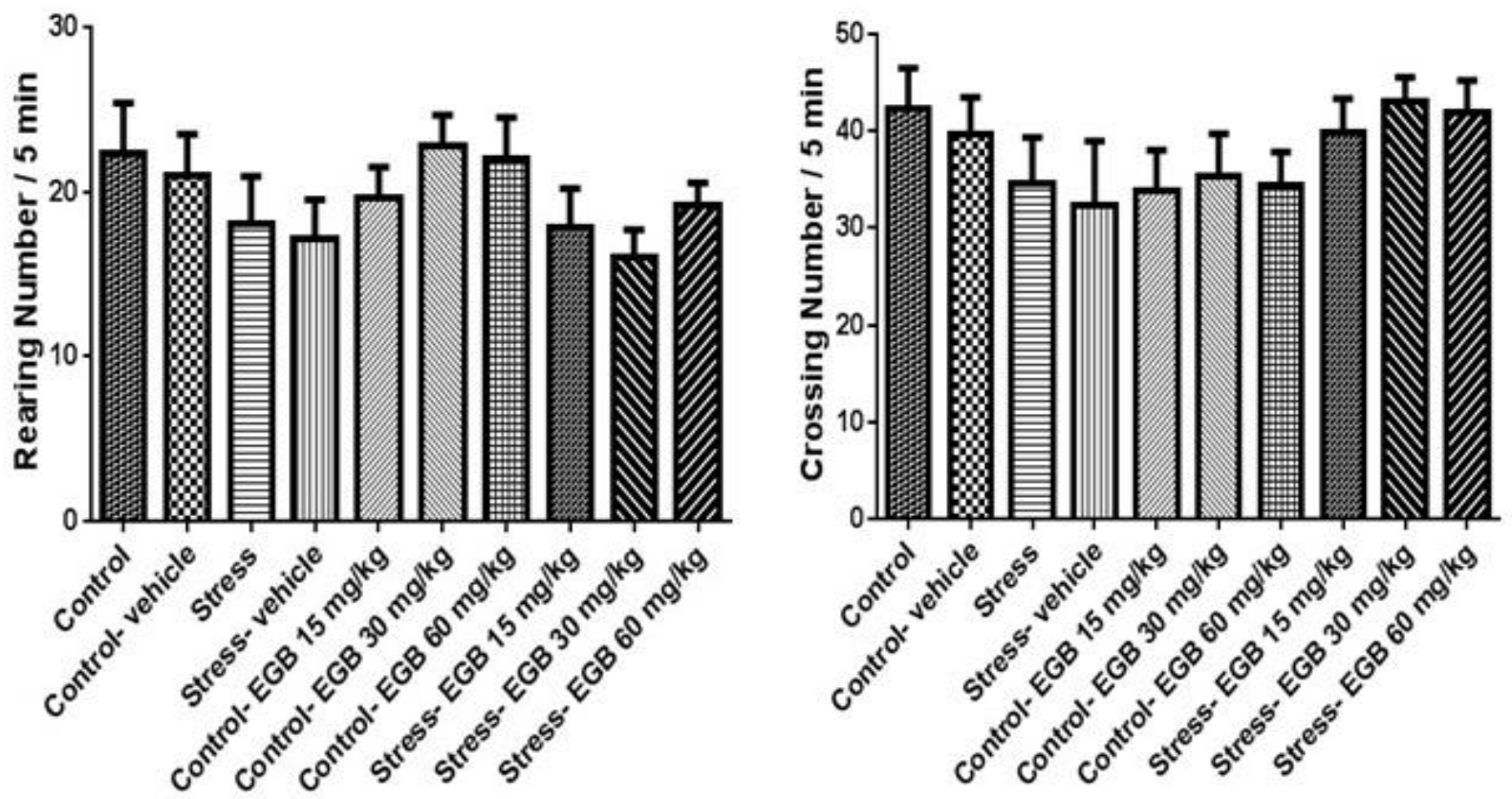

Fig.1. Effect of EGb treatment on locomotor activity of stressed rats (mean \pm SEM), EGb: Ginkgo biloba extract. Data were analyzed by One-way ANOVA.

Table 2: Effect of EGb treatment on immobility time of stressed rats in forced swimming test (mean $\pm S E M)$.

\begin{tabular}{|c|c|c|c|c|c|c|c|c|c|c|}
\hline Group & Control & $\begin{array}{l}\text { Control - } \\
\text { Vehicle }\end{array}$ & Stress & $\begin{array}{l}\text { Stress- } \\
\text { Vehicle }\end{array}$ & $\begin{array}{c}\text { Control- } \\
\text { EGb } \\
15 \mathrm{mg} / \mathrm{kg}\end{array}$ & $\begin{array}{l}\text { Control } \\
\text { - EGb } \\
30 \mathrm{~g} / \mathrm{kg}\end{array}$ & $\begin{array}{c}\text { Control- } \\
\text { EGb } \\
60 \\
\mathrm{mg} / \mathrm{kg}\end{array}$ & $\begin{array}{c}\text { Stress- } \\
\text { EGb } \\
15 \\
\mathrm{mg} / \mathrm{kg}\end{array}$ & $\begin{array}{c}\text { Stress- } \\
\text { EGb } 30 \\
\text { mg/kg }\end{array}$ & $\begin{array}{c}\text { Stress- } \\
\text { EGb } \\
60 \\
\mathrm{mg} / \mathrm{kg}\end{array}$ \\
\hline \multicolumn{11}{|l|}{ Immobility } \\
\hline $\begin{array}{l}\text { Behaviour } \\
\text { (Sec) }\end{array}$ & $\begin{array}{l}86.8 \pm \\
8.3\end{array}$ & $\begin{array}{l}91.33 \pm \\
11.1\end{array}$ & $\begin{array}{l}218 \pm \\
9^{\alpha}\end{array}$ & $\begin{array}{l}224.8 \pm \\
11.4^{\alpha}\end{array}$ & $\begin{array}{l}87.17 \pm \\
6.98\end{array}$ & $\begin{array}{l}89.83 \pm \\
7.5\end{array}$ & $\begin{array}{l}93.33 \pm \\
9.2\end{array}$ & $\begin{array}{l}182.7 \pm \\
15.7^{\alpha}\end{array}$ & $\begin{array}{l}131 \pm \\
8.1^{\Phi}\end{array}$ & $\begin{array}{l}93.83 \\
\pm 9.2^{\Phi}\end{array}$ \\
\hline $\begin{array}{l}\text { EGb: Gin } \\
60 \mathrm{mg} / \mathrm{kg}) \\
\text { analyzed }\end{array}$ & ups; ${ }^{\oplus}$ & $\begin{array}{l}\text { ract. } \\
\text { o01 com } \\
\text { JOVA. }\end{array}$ & red to & ss, str & vehicle & tress & B trea & $15 \mathrm{mg} /$ & ated ( & $\begin{array}{l}30 \text { and } \\
\text { a were }\end{array}$ \\
\hline
\end{tabular}

EGb 30 and $60 \mathrm{mg} / \mathrm{kg}(P<0.001)$ compared to the stressed groups $(F(9,50)=29.47$, the overall effect size $\mathrm{f}=2.8$; Table 1 ).

\section{Effects of Gb extract on locomotor activity in the stressed rat}

Here, $24 \mathrm{~h}$ after the last session of stress phase, the locomotor activity was analysed during $5 \mathrm{~min}$ in all groups $(n=6)$. No significant $G b$ treatment effect was detected in the number of rearing $F(9,50)=1.06$, (the overall effect size $f=0.39$ ) and crossing $F(9,50)=0.9$, (the overall effect size $f=0.37$ ) of stressed rats compared to control groups (Fig. 1).

\section{the FST}

One-way ANOVA analysis revealed that 30 and $60 \mathrm{mg} / \mathrm{kg}$ of $\mathrm{Gb}$ extract reduced the immobility time of rats in the FST $(P<0.001)$ compared to stressed rats. Immobility time significantly increased in stressed and experimental groups treated with $15 \mathrm{mg} / \mathrm{kg}$ of $\mathrm{Gb}$ extract $(P<0.001)$, as compared to control rats $(n=6$ in each group, $F(9,50)=32.88$, the overall effect size $\mathrm{f}=2.2$; Table 2).

\section{Effects of $\mathrm{Gb}$ extract on serum corticosterone} response in the stressed rat

According to One-way ANOVA analysis, chronic stress induced a dramatic rise in the level of serum corticosterone in the stressed and experimental 


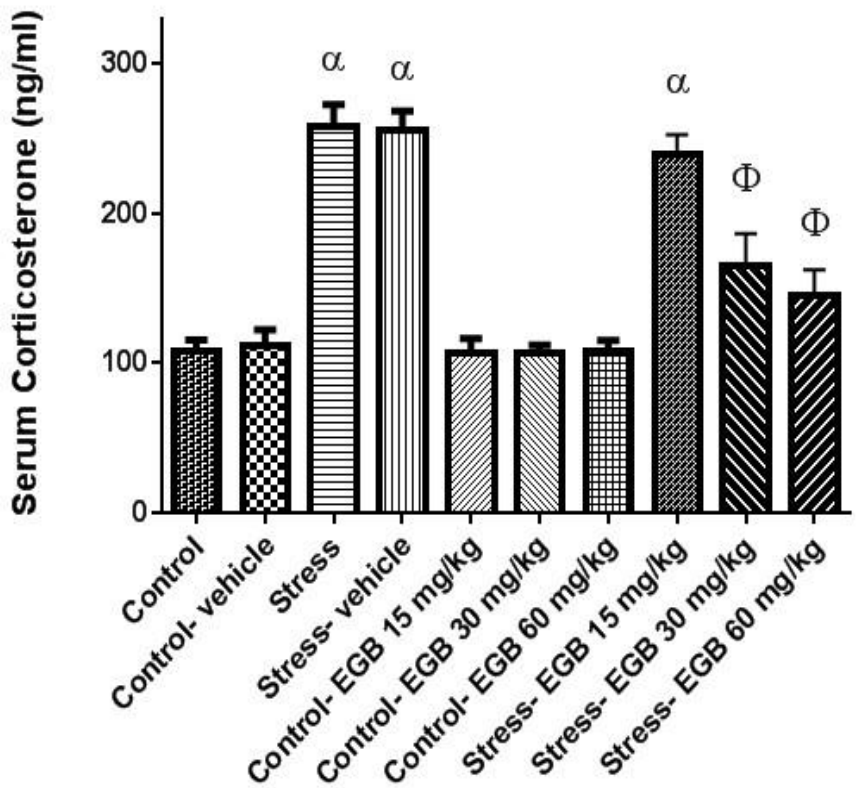

Fig.2. Effect of EGb treatment on corticosterone response of stressed rats (mean \pm SEM). EGb: Ginkgo biloba extract. ${ }^{\alpha} P<0.001$ compared to control, control - vehicle and control-EGB treated $(15,30$ and $60 \mathrm{mg} / \mathrm{kg}) \mathrm{groups} ;{ }^{\Phi} P<0.001$ compared to stress, stress- vehicle and stress- EGB treated $(15 \mathrm{mg} / \mathrm{kg})$ groups. Data were analyzed by One-way ANOVA.

group treated with EGb $15 \mathrm{mg} / \mathrm{kg}(P<0.001)$ compared to the control groups. On the other hand, the serum corticosterone response was not significantly different between the experimental groups treated with EGb 30 as well as $60 \mathrm{mg} / \mathrm{kg}$ and control groups. Further, pre-treatment with EGb 30 and $60 \mathrm{mg} / \mathrm{kg}$ attenuated $(P<0.001)$ the stress-induced growth in the serum corticosterone concentration $(n=6$ in each group, $F(9,50)=25.94$, the overall effect size $f=1.9$ compared to control groups; Fig. 2).

\section{Effects of Gb extract on hippocampal BDNF DNA methylation in the stressed rat}

ANOVA analysis of DNA methylation indicated that chronic stress daily for 21 days resulted in a significant increment in methylation status of the exon IV of BDNF $(P<0.001)$ gene in the hippocampus of adult male rats compared to the non-stressed male rats (Fig. 3). Hypermethylation of the hippocampal BDNF promoter was observed in stressed group $(P<0.001)$ and in those administered a vehicle or EGb $15(P<0.001)$ compared to the control groups. DNA hypermethylation induced by chronic stress was markedly attenuated $(P<0.001)$ with 30 and $60 \mathrm{mg} / \mathrm{kg}$ of $\mathrm{Gb}$ extract pretreatment ( $\mathrm{n}=6$ in each group, $F(9,50)=51.33$, the overall effect size $f=2.7$; Fig. 3 ).

\footnotetext{
Effects of $\mathrm{Gb}$ extract on hippocampal BDNF protein expression in the stressed rat
}

Hippocampal protein samples were evaluated for changes in BDNF expression. The antibody specifically recognizes the band for BDNF on the blot at about $28 \mathrm{kDa}$. Densitometric analysis indicated that following the chronic stress induction phase, hippocampal BDNF protein expression of male rat decreased in stress, stress- vehicle and stress- EGb $15 \mathrm{mg} / \mathrm{kg}$ treated groups $(\mathrm{n}=6, \quad P<0.001)$ in comparison with the control groups $(n=6)$. However, hippocampal BDNF protein expression was significantly enhanced in experimental groups treated with EGb $30(\mathrm{n}=6, P<0.001)$ and $60 \mathrm{mg} / \mathrm{kg}(\mathrm{n}=6$, $P<0.001)$ compared to the stressed groups ( $n=6$, $F(9,50)=15.15$, the overall effect size $f=1.5$; Fig. 4).

\section{Discussion}

This study investigated the antidepressant effect of $\mathrm{Gb}$ extract through modulation of hippocampal BDNF expression induced by RRS in adult male rats. For this purpose, we studied the Gb effect on depressivelike behaviour, endocrine responses, as well as hippocampal BDNF gene methylation and protein expression in RRS rats. Our findings revealed that pre-treatment with 30 and $60 \mathrm{mg} / \mathrm{kg}$ of $\mathrm{Gb}$ extract significantly attenuated the chronic stress-induced alterations including increased immobility time in the FST, serum corticosterone and BDNF DNA methylation level, as well as reduced protein expression of this gene in the hippocampus of the 
A
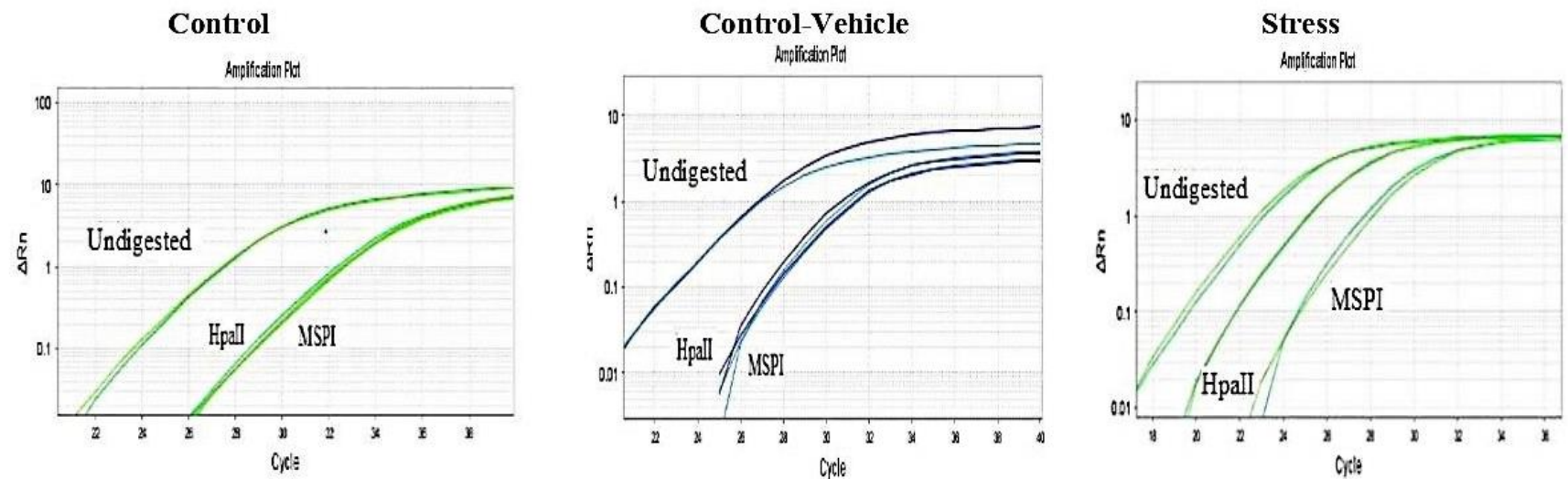

Stress-Vehicle

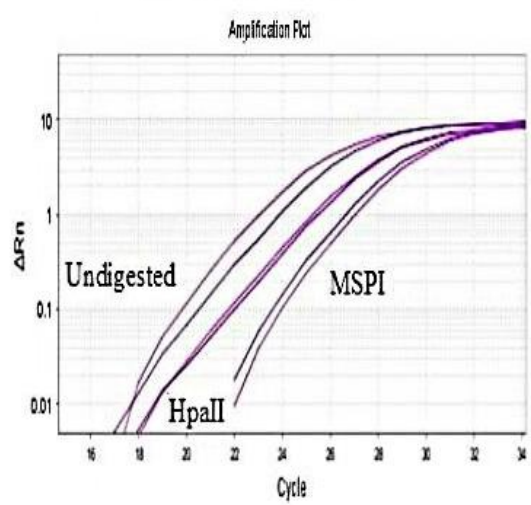

Control- EGb (15mg/ kg)

\section{Control- EGb (30mg/kg)}
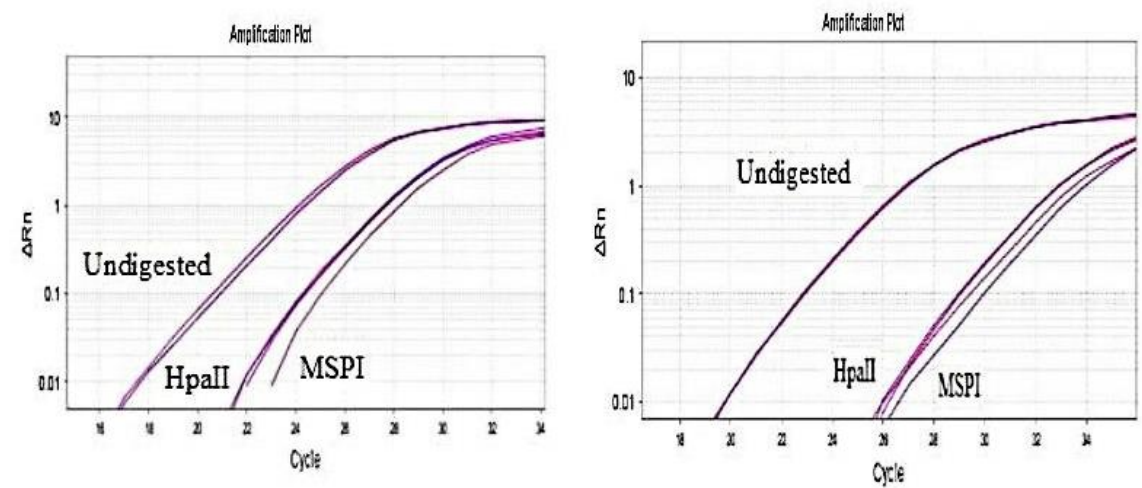

Control- EGb $(60 \mathrm{mg} / \mathrm{kg})$

Stress- EGb (15mg/ kg)
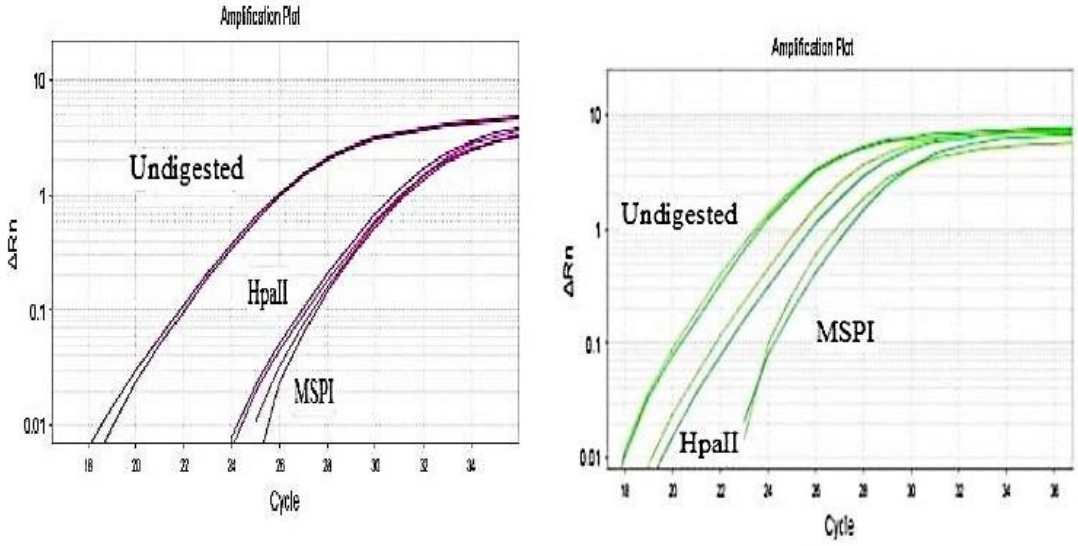

\section{Stress- EGb (30mg/ kg)}

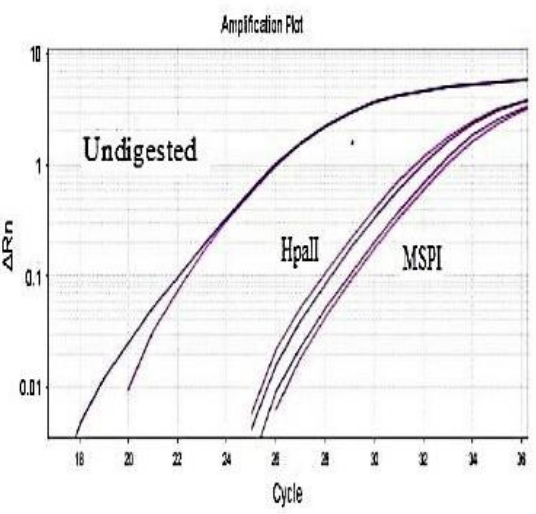

Stress- EGb (60 mg/ kg)

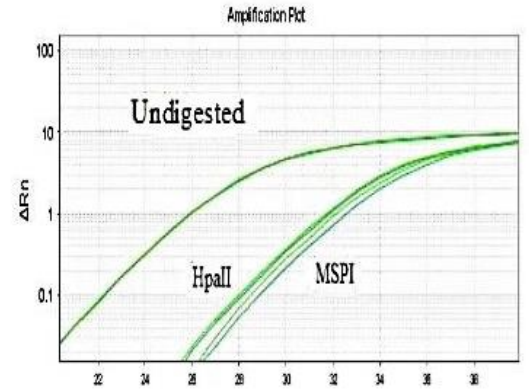




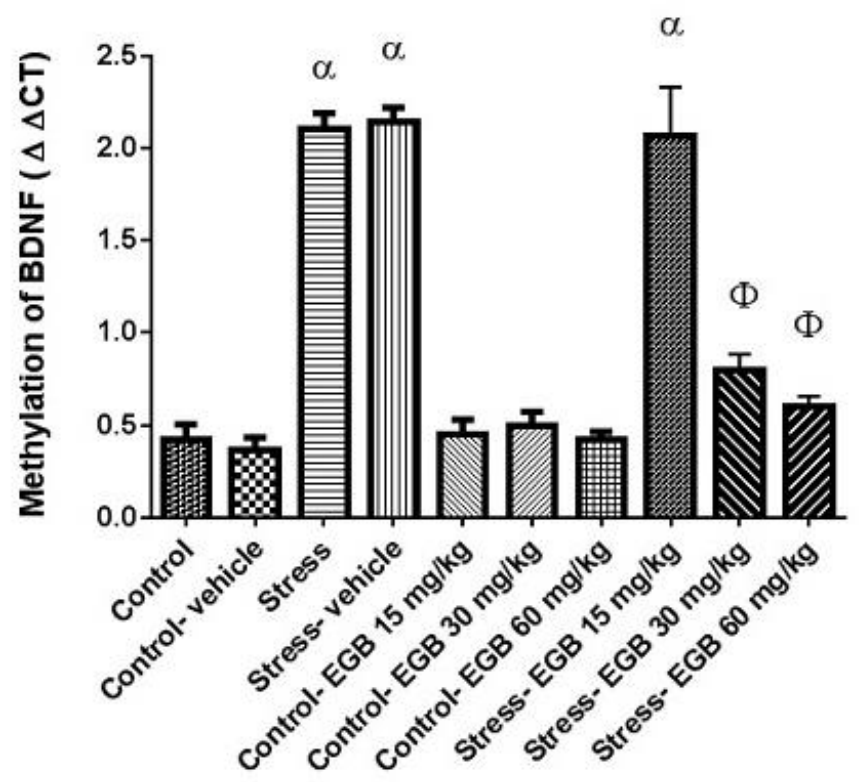

Fig.3. Effect of EGb treatment on the hippocampal BDNF DNA Methylation of stressed rats (mean $\pm S E M)$. EGb: Ginkgo biloba extract. (A) The DNA methylation level of hippocampal BDNF was assayed by Real Time $\mathrm{PCR}(\mathrm{B}){ }^{\alpha} P<0.001$ compared to control, control - vehicle and control-EGB treated $(15,30$ and $60 \mathrm{mg} / \mathrm{kg})$ groups; ${ }^{\Phi} P<0.001$ compared to stress, stress- vehicle and stress- EGB treated $(15 \mathrm{mg} / \mathrm{kg})$ groups. Data were analyzed by One-way ANOVA.

A

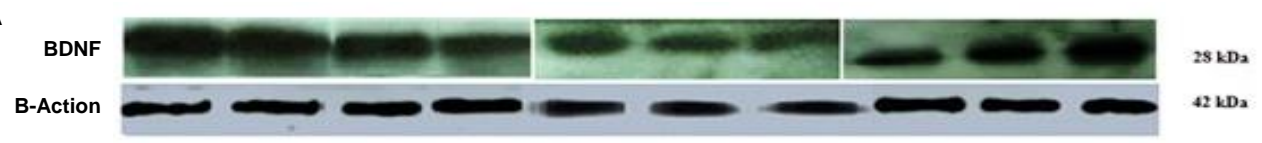

B

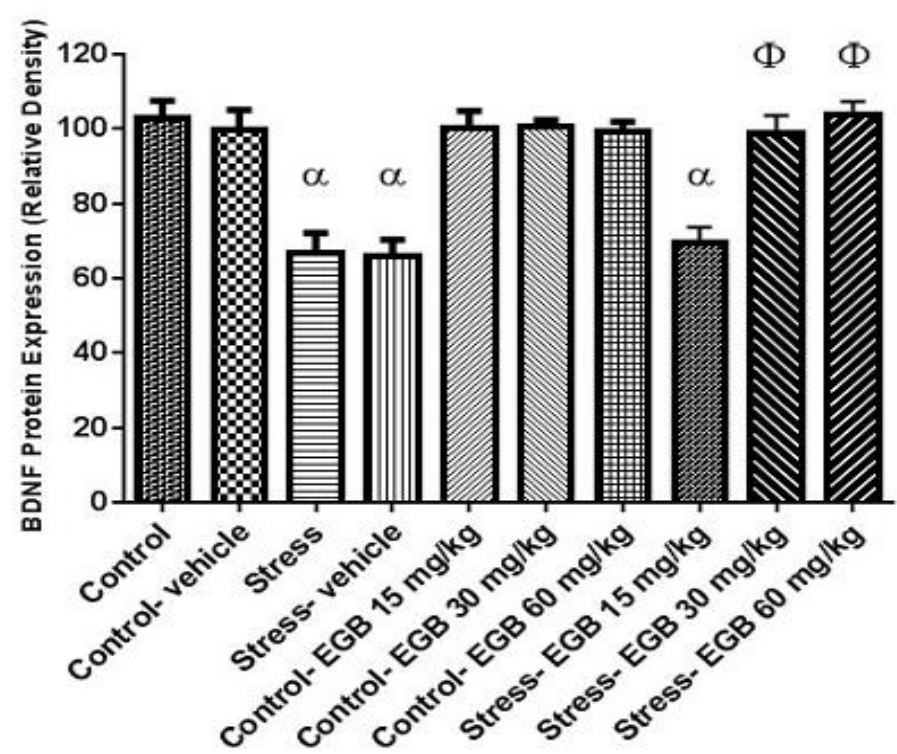

Fig.4. Effect of EGb treatment on the hippocampal BDNF protein expression of stressed rats (mean \pm SEM). EGb: Ginkgo biloba extract. (A) The protein level of BDNF was assayed by Western blot. (B) ${ }^{\alpha} P<0.001$ compared to control, control vehicle and control-EGB treated $(15,30$ and $60 \mathrm{mg} / \mathrm{kg})$ groups; ${ }^{\Phi} P<0.001$ compared to stress, stress- vehicle and stressEGB $(15 \mathrm{mg} / \mathrm{kg})$ groups. Data were analyzed by One-way ANOVA. 
animals. However, the locomotor activity of rats was not significantly altered. Indeed, locomotor activity was performed before FST to show that despite the normal locomotion of animals they were immobile in the FST test.

False-positive may result from some drugs such as sedatives, stimulants or motor-impairing compounds which could influence the immobility time even if they are free of antidepressant action (Slattery and Cryan, 2012). Our results suggested that the anti-immobility effect of Gb extract was not associated with motor deficits, as the animals treated with EGB 761 did not experience impaired locomotor activity. Thus, reduced immobility time of treated rats in the FST is not due to the effect on locomotor activity. Although FST is mostly used to assess the antidepressant effectiveness of novel drugs, the FST has also been used by a large number of studies to test depressive behaviours in animal models of mood disorders (Amiri et al., 2015; Andre et al., 2014; Brenes et al., 2008; Zheng et al., 2016). In addition, increased serum corticosterone concentration has been consistent with previous studies suggesting that physiological responses to repeated stress are associated with activation of the hypothalamicpituitary-adrenal axis (Niknazar et al., 2013; Niknazar et al., 2016; Ottenweller et al., 1992). Other results of the current study showed decreased expression of hippocampal BDNF and increased methylation of this gene in the stressed groups as compared to control. BDNF expression in the brain is regulated by stress. The role of BDNF has been found in the pathogenesis of depression and post-traumatic stress disorder (Bus et al., 2015; Li et al., 2009). A previous study noted that treatment with BDNF reversed the depression-like behaviour in an animal model of depression (Shirayama et al., 2002). Human studies have also provided findings supporting the role of BDNF in mood disorders. Chen et al. (2001) determined that BDNF levels are elevated in the hippocampus of individuals treated with antidepressant drugs in comparison to those not treated with anti-depressant medications at the time of death. Also, Karge et al. (2002) reported that serum BDNF levels decreased in 30 patients with major depression. Another key finding according to Sklar et al. (2002) was supporting the role of BDNF in the biology of mood disorders, suggesting that the BDNF gene was a predisposing factor in depression.
In addition, depression is associated with a reduction in BDNF- tyrosine kinase receptor (TrkB) signalling pathway. In rats, decreased BDNF-TrkB signalling could enhance their resistance to anti-depressant treatment in FST (Saarelainen et al., 2003). Several studies have concluded that changes in BDNF DNA methylation can be considered as a biomarker of neuropsychiatric disorders such as major depression and schizophrenia (Zheleznyakova et al., 2016). Epigenetic alteration in gene transcription has recently been proposed as a regulator of the essential gene expression changes in neural plasticity, which may also be affected by stress. DNA methylation and histone acetylation are epigenetic modifications that may lead to increase or suppress transcription of the gene (Franklin and Mansuy, 2010; Sabunciyan et al., 2012; Suzuki and Bird, 2008). Several studies have suggested that chronic restraint stress induces a depressive-like state. Indeed, this model, as a type of chronic stress, is a wellestablished source of stress which causes depressive behaviour in rats (Chiba et al., 2012; Lee et al., 2013; Naert et al., 2011; Wang et al., 2017). It has been reported that immobilization stress for one or several days (2 hours/ day) considerably reduces BDNF mRNA level in the hippocampus of rats (Smith et al., 1995b). In addition, Ueyama et al. (1997) revealed that male rats subjected to prolonged immobilization stress exhibited decreased levels of neurotrophins (BDNF, nerve growth factor and Neurotrophin-3) of the brain especially in the hippocampus. Increases in DNA methylation level of BDNF exon IV and simultaneous reductions in BDNF mRNA and protein expression were reported in rats experiencing chronic and traumatic stress (Niknazar et al., 2016; Niknazar et al., 2017a; Roth et al., 2011). In addition, studies of human post-mortem brain tissue sample obtained from suicide victims revealed significant BDNF IV region hypermethylation (Kang et al., 2013) and a simultaneous decline in BDNF mRNA in the Wernicke area compared to no-suicidal subjects (Keller et al., 2010). Today, medicinal plants, as a conventional treatment, are used for preventing and treating depression and anxiety symptoms (Fajemiroye et al., 2016). The results of a previous study suggested that $\mathrm{Gb}$ restored brain catecholamines, serotonin and plasma corticosterone responses to stress in rats exposed to forced immobilization (Shah et al., 2003). Flavonoids (glycosides) and terpenoids (ginkgolide) 
are primary active constituents of Ginkgo's leaves' extract (Biber, 2003; Deng and Zito, 2003; Diamond et al., 2000; Sticher, 1993; Victoire et al., 1988). Standardized Ginkgo preparation, EGb 761, has 24\% ginkgo flavone glycosides and 6\% terpenoids (Chan et al., 2007; DeFeudis, 2003; DeFeudis and Drieu, 2000; Yoshitake et al., 2010). This heterogeneous chemical constituent of EGb 761 and synergistic action of its components generate its neuroprotective effects against psychiatric disorders (Montes et al., 2015). In addition, several studies have indicated mild side effects of EGb 761. Gavrilova et al. (2014) demonstrated that EGb 761 improves neuropsychiatric symptoms and cognitive performance in patients with mild cognitive impairment. Their findings suggested that EGb 761 is safe and well tolerated in patients. In addition, a study by Carlson et al. (2007) concluded that Ginkgo biloba product is safe and improve quality of life in cognitively intact older people. Other studies have indicated that the components of Ginkgo biloba leaf extracts (GB), mainly the flavonoid, possess antidepressant behavioural effects and improve cognitive function through several mechanisms. They include changes in the level of neurotransmitters such as norepinephrine, dopamine, serotonin and acetylcholine as well as in neurotrophins (Hou et al., 2010; Kehr et al., 2012; Malireddy et al., 2012; Yoshitake et al., 2010). Epigenetic modifications have recently been proposed as a significant gene expression regulator and may also be affected by stress-related disorders. Epigenetic changes usually influence DNA methylation and acetylation of histones which are associated with augmented or repressed gene transcription (Gräff and Mansuy, 2008; Miranda and Jones, 2007; Vaissière et al., 2008). Methylation of cytosine residues in mammalian genomic DNA is catalysed by DNA methyltransferases (DNMTs) enzyme. Epigenetic studies have shown that subclasses of flavonoids such as flavones reduce DNMT enzyme activity and reverse DNA hypermethylation of cytosine bases in CPG-rich region, which can lead to its anti-cancer effect (Kanwal et al., 2016). Researchers have concluded that the dietary flavones can act as DNMT inhibitors. Flavonoids can also function as DNMT enzyme inhibitor both directly through interaction with the active site of the enzymes and through indirect mechanisms (Venturelli et al., 2016).

\section{Conclusion}

Overall, this study revealed that repeated administration of the extract of Ginkgo's leaves alongside with the stress paradigm may prevent the effects of chronic stress. The main finding of the study was the drug-mediated prevention of a decrease in BDNF protein expression which supported by increased methylation patterns in the BDNF promoter. Although the current work showed one of the molecular mechanisms behind the $\mathrm{Gb}$ antidepressant effect, future research is required to fully explain the mechanisms that can mediate the antidepressant action of $\mathrm{Gb}$.

\section{Acknowledgments}

This work was supported by the Phytochemistry and Hearing Disorder Research Center of Shahid Beheshti University of Medical Sciences.

\section{Conflict of interest}

The authors declare no conflict of interest.

\section{References}

Amiri S, Haj-Mirzaian A, Rahimi-Balaei M, Razmi A Kordjazy N, Shirzadian A, et al. Co-occurrence of anxiety and depressive-like behaviors following adolescent social isolation in male mice; possible role of nitrergic system. Physiol Behav 2015; 145: 38-44. https://doi.org/10.1016/j.physbeh.2015.03.032

Andre C, Dinel AL, Ferreira G, Laye S, Castanon N. Dietinduced obesity progressively alters cognition, anxietylike behavior and lipopolysaccharide-induced depressive-like behavior: focus on brain indoleamine 2 , 3-dioxygenase activation. Brain Behav Immun 2014; 41: 10-21. https://doi.org/10.1016/j.bbi.2014.03.012

Bakhtiarzadeh F, Nahavandi A, Goudarzi M, Shirvalilou S, Rakhshan K, Niknazar S. Axonal transport proteins and depressive like behavior, following Chronic Unpredictable Mild Stress in male rat. Physiol Behav 2018; 194: 9-14. https://doi.org/10.1016/j.physbeh.2018. 04.029

Belmaker R, Agam G. Major depressive disorder. N Engl J Med 2008; 358: 55-68. https://doi.org/10.1056/ NEJMra073096

Biber A. Pharmacokinetics of Ginkgo biloba extracts. Pharmacopsychiatry 2003; 36: 32-37. https://doi.org/ $10.1055 / \mathrm{s}-2003-40446$

Brenes JC, Rodríguez O, Fornaguera J. Differential effect of environment enrichment and social isolation on depressive-like behavior, spontaneous activity and serotonin and norepinephrine concentration in prefrontal 
cortex and ventral striatum. Pharmacol Biochem Behav 2008; 89: 85-93. https://doi.org/10.1016/j.pbb.2007. 11.004

Bus BA, Molendijk ML, Tendolkar I, Penninx BW, Prickaerts $\mathrm{J}$, Elzinga BM, et al. Chronic depression is associated with a pronounced decrease in serum brain-derived neurotrophic factor over time. Mol Psychiatry 2015; 20: 602-8. https://doi.org/10.1038/mp.2014.83

Carlson JJ, Farquhar JW, DiNucci E, Ausserer L, Zehnder J, Miller D, et al. Safety and efficacy of a Ginkgo bilobacontaining dietary supplement on cognitive function, quality of life, and platelet function in healthy, cognitively intact older adults. J Am Diet Assoc 2007; 107: 422-32. https://doi.org/10.1016/j.jada.2006.12.011

Chan PC, Xia Q, Fu PP. Ginkgo biloba leave extract: biological, medicinal, and toxicological effects. J Environ Sci Heal C 2007; 25: 211-44. https://doi.org/10.1080/ 10590500701569414

Chandrasekaran K, Mehrabian Z, Spinnewyn B, Drieu K, Fiskum G. Neuroprotective effects of bilobalide, a component of the Ginkgo biloba extract (EGb 761), in gerbil global brain ischemia. Brain Res 2001; 922: 28292. https://doi.org/10.1016/S0006-8993(01)03188-2

Chen B, Dowlatshahi D, MacQueen GM, Wang JF, Young LT. Increased hippocampal BDNF immunoreactivity in subjects treated with antidepressant medication. Biol Psychiatry 2001; 50: 260-5. https://doi.org/10.1016/ S0006-3223(01)01083-6

Chiba S, Numakawa T, Ninomiya M, Richards MC, Wakabayashi $\mathrm{C}$, Kunugi $\mathrm{H}$. Chronic restraint stress causes anxiety-and depression-like behaviors, downregulates glucocorticoid receptor expression, and attenuates glutamate release induced by brain-derived neurotrophic factor in the prefrontal cortex. Prog NeuroPsychopharmacology Biol Psychiatry 2012; 39: 112-9. https://doi.org/10.1016/j.pnpbp.2012.05.018

DeFeudis FV. A brief history of EGb $761 \AA$ and its therapeutic uses. Pharmacopsychiatry 2003; 36: 2-7. https://doi.org/10.1055/s-2003-40450

DeFeudis FV, Drieu K. Ginkgo biloba extract (EGb 761) and CNS functions basic studies and clinical applications. Curr Drug Targets 2000; 1: 25-58. https://doi.org/10.2174/1389450003349380

Deng F, Zito SW. Development and validation of a gas chromatographic-mass spectrometric method for simultaneous identification and quantification of marker compounds including bilobalide, ginkgolides and flavonoids in Ginkgo biloba L. extract and pharmaceutical preparations. J Chromatogr A 2003; 986: 121-7. https://doi.org/10.1016/S0021-9673(02) 01921-0

Diamond BJ, Shiflett SC, Feiwel N, Matheis RJ, Noskin O, Richards JA, et al. Ginkgo biloba extract: mechanisms and clinical indications. Arch Phys Med Rehabil 2000; 81: 668-78. https://doi.org/10.1016/S0003-9993(00) 90052-2

Fajemiroye JO, da Silva DM, de Oliveira DR, Costa EA. Treatment of anxiety and depression: medicinal plants in retrospect. Fundam Clin Pharmacol 2016; 30: 198-
215. https://doi.org/10.1111/fcp.12186

Franklin TB, Mansuy IM. The prevalence of epigenetic mechanisms in the regulation of cognitive functions and behaviour. Curr Opin In Neurobiol 2010; 20: 441-9. https://doi.org/10.1016/j.conb.2010.04.007

Gavrilova SI, Preuss UW, Wong JW, Hoerr R, Kaschel R, Bachinskaya N, et al. Efficacy and safety of Ginkgo biloba extract $E G b 761 \AA$ in mild cognitive impairment with neuropsychiatric symptoms: a randomized, placebo-controlled, double-blind, multi-center trial. Int J Geriatr Psychiatry 2014; 29: 1087-95. https://doi.org/10.1002/gps.4103

Gräff J, Mansuy IM. Epigenetic codes in cognition and behaviour. Behav Brain Res 2008; 192: 70-87. https://doi.org/10.1016/j.bbr.2008.01.021

Hashimoto K, Shimizu E, lyo M. Critical role of brainderived neurotrophic factor in mood disorders. Brain Res Reviews 2004; 45: 104-14. https://doi.org/ 10.1016/j.brainresrev.2004.02.003

Hidaka BH. Depression as a disease of modernity: explanations for increasing prevalence. J Affect Disord 2012; 140: 205-14. https://doi.org/10.1016/j.jad.2011 .12 .036

Hou Y, Aboukhatwa MA, Lei DL, Manaye K, Khan I, Luo Y. Anti-depressant natural flavonols modulate BDNF and beta amyloid in neurons and hippocampus of double TgAD mice. Neuropharmacology 2010; 58: 911-20. https://doi.org/10.1016/j.neuropharm.2009.11.002

Howes MJ, Houghton PJ. Plants used in Chinese and Indian traditional medicine for improvement of memory and cognitive function. Pharmacol Biochem Behav 2003; 75: 513-27. https://doi.org/10.1016/S0091-3057 (03)00128-X

Jaenisch R, Bird A. Epigenetic regulation of gene expression: how the genome integrates intrinsic and environmental signals. Nat Genet 2003; 33: 245-54. https://doi.org/10.1038/ng1089

Kang HJ, Kim JM, Lee JY, Kim SY, Bae KY, Kim SW, et al. BDNF promoter methylation and suicidal behavior in depressive patients. J Affect Disord 2013; 151: 679-85. https://doi.org/10.1016/j.jad.2013.08.001

Kanwal R, Datt M, Liu X, Gupta S. Dietary Flavones as Dual Inhibitors of DNA Methyltransferases and Histone Methyltransferases. PloS one 2016; 11: e0162956. https://doi.org/10.1371/journal.pone.0162956

Karege F, Perret G, Bondolfi G, Schwald M, Bertschy G, Aubry JM. Decreased serum brain-derived neurotrophic factor levels in major depressed patients. Psychiatr Res 2002; 109: 143-8. https://doi.org/10.1016/S0165-1781 (02)00005-7

Kehr J, Yoshitake S, ljiri S, Koch E, Nöldner M, Yoshitake T. Ginkgo biloba leaf extract (EGb 761®) and its specific acylated flavonol constituents increase dopamine and acetylcholine levels in the rat medial prefrontal cortex: possible implications for the cognitive enhancing properties of EGb $761 \AA$. Int Psychogeriatr 2012; 24: S25. https://doi.org/10.1017/S1041610212 000567

Keller S, Sarchiapone M, Zarrilli F, Videtič A, Ferraro A, 
Carli V, et al. Increased BDNF promoter methylation in the Wernicke area of suicide subjects. Arch 2010; 67: 258-67. https://doi.org/10.1001/archgenpsychiatry .2010 .9

Lee B, Sur B, Park J, Kim SH, Kwon S, Yeom M, et al. Chronic administration of baicalein decreases depression-like behavior induced by repeated restraint stress in rats. Korean J Physiol Pharmacol 2013; 17: 393-403. https://doi.org/10.4196/kjpp.2013.17.5.393

Li Y, Ji YJ, Jiang H, Liu DX, Zhang Q, Fan SJ, et al. Effects of unpredictable chronic stress on behavior and brainderived neurotrophic factor expression in CA3 subfield and dentate gyrus of the hippocampus in different aged rats. Chin Med J 2009; 122: 1564-9.

Malireddy S, Kotha SR, Secor JD, Gurney TO, Abbott JL, Maulik G, et al. Phytochemical antioxidants modulate mammalian cellular epigenome: implications in health and disease. Antioxid Redox Signal 2012; 17: 327-39. https://doi.org/10.1089/ars.2012.4600

Malykhin NV, Coupland NJ. Hippocampal neuroplasticity in major depressive disorder. Neuroscience 2015; 309: 200-13. https://doi.org/10.1016/j.neuroscience.2015.04 .047

Mineka S, Watson D, Clark L A. Comorbidity of anxiety and unipolar mood disorders. Annu Rev Psychol 1998; 49: 377-412.https://doi.org/10.1146/annurev.psych.49.1.377

Miranda TB, Jones PA. DNA methylation: the nuts and bolts of repression. J Cell Physiol 2007; 213: 384-90. https://doi.org/10.1002/jcp.21224

Montes P, Ruiz-Sanchez E, Rojas C, Rojas P. Ginkgo biloba extract 761: a review of basic studies and potential clinical use in psychiatric disorders. CNS Neurol Disord Drug Targets 2015; 14: 132-149. https://doi.org/10.2174/1871527314666150202151440

Naert G, Ixart G, Maurice T, Tapia-Arancibia L, Givalois L. Brain-derived neurotrophic factor and hypothalamicpituitary-adrenal axis adaptation processes in a depressive-like state induced by chronic restraint stress. Mol Cell Neurosci 2011; 46: 55-66. https://doi.org/10.1016/j.mcn.2010.08.006

Niknazar S, Nahavandi A, Najafi R, Danialy S, Mehrjerdi FZ, Karimi M. Parents' adulthood stress induces behavioral and hormonal alterations in male rat offspring. Behav Brain Res 2013; 252: 136-43. https://doi.org/10.1016/j.bbr.2013.05.026

Niknazar S, Nahavandi A, Peyvandi AA, Peyvandi $H$, Akhtari AS, Karimi M. Comparison of the adulthood chronic stress effect on hippocampal BDNF signaling in male and female rats. Mol Neurobiol 2016; 53: 4026-33. https://doi.org/10.1007/s12035-015-9345-5

Niknazar S, Nahavandi A, Peyvandi AA, Peyvandi $H$, Mehrjerdi FZ, Karimi M. Effect of maternal stress prior to conception on hippocampal BDNF signaling in rat offspring. Mol Neurobiol 2017a; 54: 6436-45. https://doi.org/10.1007/s12035-016-0143-5

Niknazar S, Nahavandi A, Peyvandi AA, Peyvandi $H$, Roozbahany NA, Abbaszadeh HA. Hippocampal NR3C1 DNA methylation can mediate part of preconception paternal stress effects in rat offspring.
Behav Brain Res 2017b; 324: 71-6. https://doi.org/10.1016/j.bbr.2017.02.014

Noori-Daloii MR, Shahbazi A, Alizadeh Zendehrood S, Shayan Nia A, Mojarrad M, Kheirollahi $M$, et al. Knocking down the DRD2 by shRNA expressing plasmids in the nucleus accumbens prevented the disrupting effect of apomorphine on prepulse inhibition in rat. J Sci I R 2015; 26: 205-12.

Onishchenko N, Karpova N, Sabri F, Castrén E, Ceccatelli $S$. Long-lasting depression-like behavior and epigenetic changes of BDNF gene expression induced by perinatal exposure to methylmercury. J Neurochem 2008; 106: 1378-87. https://doi.org/10.1111/j.1471-4159.2008.054 84. $x$

Ottenweller JE, Servatius RJ, Tapp WN, Drastal SD, Bergen MT, Natelson BH. A chronic stress state in rats: effects of repeated stress on basal corticosterone and behavior. Physiol Behav 1992; 51: 689-98. https://doi.org/10.1016/0031-9384(92)90104-A

Parasuraman S, Raveendran R, Kesavan R. Blood sample collection in small laboratory animals. J Pharmacol Pharmacotherapeutics 2010; 1: 87. https://doi.org/ 10.4103/0976-500X.72350

Porsolt RD, Bertin A, Blavet N, Deniel $M$, Jalfre $M$. Immobility induced by forced swimming in rats: effects of agents which modify central catecholamine and serotonin activity. Eur J Pharmacol 1979; 57: 201-10. https://doi.org/10.1016/0014-2999(79)90366-2

Roth TL, Zoladz PR, Sweatt JD, Diamond DM. Epigenetic modification of hippocampal BDNF DNA in adult rats in an animal model of post-traumatic stress disorder. $\mathrm{J}$ Psychiatr Res 2011; 45: 919-26. https://doi.org/ 10.1016/j.jpsychires.2011.01.013

Saarelainen T, Hendolin P, Lucas G, Koponen E, Sairanen $M$, MacDonald $E$, et al. Activation of the TrkB neurotrophin receptor is induced by antidepressant drugs and is required for antidepressant-induced behavioral effects. J Neurosci 2003; 23: 349-57. https://doi.org/10.1523/JNEUROSCI.23-01-00349.2003

Sabunciyan S, Aryee MJ, Irizarry RA, Rongione M, Webster MJ, Kaufman WE, et al. Genome-wide DNA methylation scan in major depressive disorder. Plos One 2012; 7: e34451. https://doi.org/10.1371/journal.pone.0034451

Sarris J, Panossian A, Schweitzer I, Stough C, Scholey A. Herbal medicine for depression, anxiety and insomnia: a review of psychopharmacology and clinical evidence. Eur Neuropsychopharmacol 2011; 21: 841-60. https://doi.org/10.1016/j.euroneuro.2011.04.002

Shah ZA, Sharma P, Vohora SB. Ginkgo biloba normalises stress-elevated alterations in brain catecholamines, serotonin and plasma corticosterone levels. Eur neuropsychopharmacol 2003; 13: 321-5. https://doi.org/ 10.1016/S0924-977X(03)00005-1

Shirayama Y, Chen AC, Nakagawa S, Russell DS, Duman RS. Brain-derived neurotrophic factor produces antidepressant effects in behavioral models of depression. J Neurosci 2002; 22: 3251-61. https://doi.org/10.1523/JNEUROSCI.22-08-03251.2002

Sklar P, Gabriel S, Mclnnis MG, Bennett P, Lim YM, Tsan 
G, et al. Family-based association study of 76 candidate genes in bipolar disorder: BDNF is a potential risk locus. Mol Psychiatry 2002; 7: 579-93. https://doi.org /10.1038/sj.mp.4001058

Slattery DA, Cryan JF. Using the rat forced swim test to assess antidepressant-like activity in rodents. Nat Protoc 2012; 7: 1009-14. https://doi.org/10.1038/ nprot.2012.044

Smith MA, Makino SH, Kim SY, Kvetnansky RI. Stress increases brain-derived neurotropic factor messenger ribonucleic acid in the hypothalamus and pituitary. Endocrinol 1995a; 136: 3743-50. https://doi.org/10.1210/ endo.136.9.7649080

Smith MA, Makino S, Kvetnansky R, Post RM. Stress and glucocorticoids affect the expression of brain-derived neurotrophic factor and neurotrophin-3 mRNAs in the hippocampus. J Neurosci 1995b; 15: 1768-77. https://doi.org/10.1523/JNEUROSCI.15-03-01768.1995

Spina MB, Squinto SP, Miller J, Lindsay RM, Hyman C. Brain-derived neurotrophic factor protects dopamine neurons against 6-hydroxydopamine and N-methyl-4phenylpyridinium ion toxicity: involvement of the glutathione system. J Neurochem 1992; 59: 99-106. https://doi.org/10.1111/j.1471-4159.1992.tb08880.x

Sticher O. Quality of ginkgo preparations1. Planta Med 1993; 59: 2-11. https://doi.org/10.1055/s-2006-959593

Suzuki MM, Bird A. DNA methylation landscapes: provocative insights from epigenomics. Nat Rev Genet 2008; 9: 465-76. https://doi.org/10.1038/nrg2341

Tsankova NM, Berton O, Renthal W, Kumar A, Neve RL, Nestler EJ. Sustained hippocampal chromatin regulation in a mouse model of depression and antidepressant action. Nat Neurosci 2006; 9: 519-25. https://doi.org/10.1038/nn1659

Tsankova NM, Kumar A, Nestler EJ. Histone modifications at gene promoter regions in rat hippocampus after acute and chronic electroconvulsive seizures. J Neurosci 2004; 24: 5603-10. https://doi.org/10.1523/ JNEUROSCI.0589-04.2004

Ueyama T, Kawai $Y$, Nemoto $K$, Sekimoto $M$, Toné $S$, Senba E. Immobilization stress reduced the expression of neurotrophins and their receptors in the rat brain. Neurosci Res 1997; 28: 103-10. https://doi.org/10.1016 /S0168-0102(97)00030-8

Vaissière T, Sawan C, Herceg Z. Epigenetic interplay between histone modifications and DNA methylation in gene silencing. Mutat Res 2008; 659: 40-8. https://doi.org/10.1016/j.mrrev.2008.02.004

Venturelli S, Burkard M, Biendl M, Lauer UM, Frank J, Busch C. Prenylated chalcones and flavonoids for the prevention and treatment of cancer. Nutrition 2016; 32 : 1171-8. https://doi.org/10.1016/j.nut.2016.03.020

Victoire C, Haag-Berrurier M, Lobstein-Guth A, Balz JP, Anton R. Isolation of flavonol glycosides from Ginkgo biloba leaves. Planta Med 1988; 54: 245-7. https://doi.org/10.1055/s-2006-962418

Wang Q, Timberlake II MA, Prall K, Dwivedi Y. The recent progress in animal models of depression. Prog Neuropsychopharmacol Biol Psychiatry 2017; 77: 99109. https://doi.org/10.1016/j.pnpbp.2017.04.008

Woelk H, Arnoldt KH, Kieser M, Hoerr R. Ginkgo biloba special extract $E G b 761 \AA$ in generalized anxiety disorder and adjustment disorder with anxious mood: a randomized, double-blind, placebo-controlled trial. J Psychiatr Res 2007; 41: 472-80. https://doi.org/10.1016 /j.jpsychires.2006.05.004

Yoshitake T, Yoshitake S, Kehr J. The Ginkgo biloba extract $\mathrm{EGb} 761 \AA$ and its main constituent flavonoids and ginkgolides increase extracellular dopamine levels in the rat prefrontal cortex. $\mathrm{Br} \mathrm{J}$ Pharmacol 2010; 159: 659-68. https://doi.org/10.1111/j.1476-5381.2009.00580 .x

Zheleznyakova GY, Cao H, Schiöth HB. BDNF DNA methylation changes as a biomarker of psychiatric disorders: literature review and open access database analysis. Behav Brain Funct 2016; 12: 17. https://doi.org/10.1186/s12993-016-0101-4

Zheng P, Zeng B, Zhou C, Liu M, Fang Z, Xu X, et al. Gut microbiome remodeling induces depressive-like behaviors through a pathway mediated by the host's metabolism. Mol Psychiatry 2016; 21: 786-96. https://doi.org/10.1038/mp.2016.44 